\title{
GANODERMA LUCIDUM-ORIENTAL MUSHROOM MEDIATED SYNTHESIS OF GOLD NANOPARTICLES CONJUGATED WITH DOXORUBICIN AND EVALUATION OF ITS ANTICANCER POTENTIAL ON HUMAN BREAST CANCER MCF-7/DOX CELLS
}

\author{
D. S. RANJITH SANTHOSH KUMAR, P. SENTHILKUMAR* L. SURENDRAN, B. SUDHAGAR
}

PG and Research Department of Biotechnology, Kongunadu Arts and Science College, Coimbatore-29, Tamilnadu, India Email: senthilkumar1185@gmail.com

Received: 19 May 2017 Revised and Accepted: 22 Jul 2017

\begin{abstract}
Objective: The present investigations are to mycosynthesis and characterization of gold nanoparticles conjugated with doxorubicin and evaluated anticancer activity.

Methods: The characterization of the gold nanoparticles using ultraviolet-visible spectroscopy. FTIR investigations were carried out to find and read the functional group responsible designed at the bioconversion of gold ions and crystalline arrangement of gold nanoparticles was detected in the XRD study. The gold nanoparticles conjugated with doxorubicin were treated against MCF-7-dox resisted breast cancer cells and observed the in vitro cytotoxicity by MTT assay, SCGE (Comet), Apoptosis and Mito-potential assay. Further more we determinate the mRNA expression of ABCB1 gene and cDNA was synthesized from the mRNA for amplification of the ABCB1 gene corresponding to the specific primer.
\end{abstract}

Results: Surface Plasmon resonance showed the development of gold nanoparticles in UV-Visible spectra at $537 \mathrm{~nm}$. The synthesized gold nanoparticles were polydisperse spherical and it was determined by EDAX and stabilized in the solution to the spherical shapes further confirmed by High-resolution transmission electron microscope analysis designate in the reading of 2-100 $\mathrm{nm}$. The anticancer assays were given significant results and the mRNA expression of $A B C B 1$ gene and CDNA was amplified as directly proportional to the expression of ABCB1 gene.

Conclusion: We propose that gold nanoparticles synthesized and conjugated with doxorubicin from G. lucidum might be a significant resource of drug delivery for anti-cancer preparation that may advantage breast cancer treatment.

Keywords: Oriental mushroom, Ganoderma lucidum, Doxorubicin, Au-NPs, 2-100 nm, Breast cancer MCF-7/Dox cells

(C) 2017 The Authors. Published by Innovare Academic Sciences Pvt Ltd. This is an open access article under the CC BY license (http://creativecommons.org/licenses/by/4.0/) DOI: http://dx.doi.org/10.22159/ijpps.2017v9i9.20093

\section{INTRODUCTION}

Life progression accounts of the variety of species adaptations comprise alterations in structures, departments, or physiology that amend and reproductive accomplishment in a particular environment. After the environmental modifications, organisms perpetuate and reproduce, and it alterations incipient biomaterials for their subsistence [1,2]. These involute modifications perpetually with developed countless amendments for the novel nanomaterials [3]. Nanomaterials have distributed a wide range of study in recent years by connecting with numerous divisions of science which form an extensive impression on total forms of life [4].

Among the nanomaterials, the nano particles contract a numerous advantage to humanity which is well-suited for pharmaceutical and biomedical applications [5]. The recent scientific investigations showing the interest in using metal, eco-friendly nanoparticles as they offer greater material properties and its advantage over medical science [6]. The biological synthesis method of nanoparticles seems to ecologically feasible approach, are found extremely stable [7]. Hence, these simple green synthesis methods provide consideration researchers in frequent ways and is incipiently developed as very few components of present nano biotechnological research.

Breast cancer is most devastating cancers most astronomically immense among women in the world, which is the second record public inception of death in women, expressive $16 \%$ of all female cancers. In 2015, a projected 231,840 incipient cases of invasive breast cancer will be identified among women, as well as an assessed 60,290 integrated cases of in situ breast cancer, virtually 40,290 women are expected to die from breast cancer [8]. Presently there are a number of chemo preventives agents are obtainable in the market, for the treatment of cancer, but they are sumptuous and engender undesirable side effects; consequently, emerging a biocompatible and cost-efficacious manner of management for cancer is essential [9]. Gold nanoparticles are the gifted occurrence in treating diseases, which have been extensively utilized for drug distribution and targeting cancer. Gold nanoparticles unparalleled connections with bimolecular both on the surface and inside the body cells, it efficaciously shows substantial activity for anticancer, antimicrobial, antifungal, antioxidant, and anti-inflammatory effects [10].

The present study describes the mycosynthesis of Au-NPs synthesized and conjugated with doxorubicin by using extracts of mushroom Ganoderma lucidum and the characterization of gold nanoparticles using the standard devices.

Ganoderma lucidum (Curtis) P. Karst. (Class: Agaricomycetes, Order: Polyporales, Family: Ganodermataceae) is commonly known as Lingzhi or Reishi, familiar across the world as an oriental mushroom with medicinal properties for over $2000 \mathrm{y}$ and its prevailing effects have been recognized in ancient scripts [11]. G. lucidum exhibits antitumor, immunomodulatory, cardiovascular, respiratory and antihepatotoxic effect $[12,13]$. The ganoderic acid, triterpenes and polysaccharides compound isolated from $G$. lucidum possess significant pharmacological activities and more than 50 carcinostatic polysaccharides have been isolated and are known to be unique compounds in this mushroom $[14,15]$. Since our research team already attempted to synthesize silver nanoparticles from G. lucidum [16].

Our research unit has for the first time reported the mycosynthesis and characterization of gold nanoparticles conjugated with drug doxorubicin using mushroom $G$. lucidum and its effects on against MCF-7-Dox resisted cells breast cancer cells. Further, the cytotoxic effects of Au-NPs synthesized and conjugated with doxorubicin were tested against MCF-7-Dox resisted cells by MTT assay and the possible mechanism for cell death was addressed through Mito potential assay, Acridine orange staining and Comet assay for DNA damage. Furthermore, in order to underline the possible mechanism 
involved in the anti-cancer activity of gold nanoparticles conjugated with doxorubicin. In our research, we have determined the possibility that the mechanism of ABCB1 expression.

\section{MATERIALS AND METHODS}

\section{Chemicals}

Reagents and chemicals used in the present study were of analytical grade.

\section{Collection and processing of mushroom materials}

Ganoderma lucidum (Curtis) P. Karst a mushroom was collected from foot hills of Maruthamalai $\left(11^{\circ} 2^{\prime} 46^{\prime \prime} \mathrm{N} 76^{\circ} 51^{\prime} 7^{\prime \prime} \mathrm{E}\right)$ is situated Western Ghats, Coimbatore, Tamilnadu, and South India and during the month of August 2016. G. lucidum was authenticated by the Mycology Division of IFGTB (Indian Forest Genetics and Tree Breeding Institute) Coimbatore and the voucher specimen (RT-25406/9-1-2016) was retained in our laboratory for future reference.

\section{Preparation of aqueous extraction}

The whole mushroom samples were healthy and fresh were transferred to the laboratory and scrubbed using a brush for the removal of the epiphytes with distilled water. After cleaning, the mushrooms were dried in shade at room temperature for one week. The fine pieces of dried samples ( $25 \mathrm{~g}$ ) were taken and boiled with sterilized distilled water $(100 \mathrm{ml})$ for not more than $5 \mathrm{~min}$. The brown-coloured crude extract is passed through Whatman No.1 filter paper and the filtrates will be stored at $4{ }^{\circ} \mathrm{C}$ for further use.

\section{Synthesis of gold nanoparticles and conjugation of doxorubicin}

Gold chloride $\left(\mathrm{HAuCl}_{4}\right)$ as analytical grade (AR) was purchased from HIMEDIA, Mumbai, India. In the synthesis of gold nanoparticles (AuNps), $10 \mathrm{ml}$ of the aqueous extract of $\mathrm{G}$. lucidum will be added to $90 \mathrm{ml}$ of $10^{-3}$ $\mathrm{M}$ aqueous HAuCl4 solution in Erlenmeyer flask $(500 \mathrm{ml})$ and stirred for $4 \mathrm{hr}$ at $120 \mathrm{rpm}$ at $40^{\circ} \mathrm{C}$. Proper controls were maintained throughout the conduct of experiments. The solution attained was transferred to an amber colour bottle to avoid anti-oxidation of gold. The solution with gold ion and mushroom extract was renowned for colour change through visual observation. Conjugation of doxorubicin was done out in $1 \mathrm{ml}$ PBS containing AuNPs (2 mmol), Dox (50 mmol), 1-ethyl-3-(3 dimethyl-aminoprophyl)-carbodimide (EDC) $(10 \mathrm{mmol})$. Conjugation was carried out in the dark at room temperature for I hour followed by dialysis against double distilled water for $3 \mathrm{~h}$.

\section{Characterization of gold nanoparticles}

The gold nanoparticles were well-defined by means of UV-Vis spectrophotometer (UV-100 Cyberlab USA) in the frequencies between 200 and $800 \mathrm{~nm}$. The moieties examination of the gold nanoparticles was carried out by FTIR spectra that were studied for the gold nanoparticles by FTIR Nicolet Avatar 660 (Nicolet, USA). Elemental analysis of the gold nanoparticles were inspected using energy dispersive X-ray spectroscopy (EDX): XRD and Highresolution transmission electron microscopy (HRTEM) was done to study the structure of the gold nanoparticles by placing of $1 \mathrm{ll}$ of the sample carbon films supported by copper grids, air dried, and viewed at $100 \mathrm{kV}$ (JEOL 1010 TEM).

\section{Cell culture}

Human breast cancer cells (MCF-7) were obtained from National Centre for Cell Science, Pune, India. DMEM was purchased from $\mathrm{Hi}$ media laboratories. Fetal bovine serum (FBS) was acquired from Cistron laboratories and trypsin, methyl thiazolyl diphenyltetrazolium bromide (MTT) and dimethyl sulfoxide (DMSO) were purchased from Sisco research laboratory chemicals Mumbai. The cells were maintained in DMEM Media supplemented with $10 \%$ FBS, penicillin $(100 \mathrm{U} / \mathrm{ml})$ and streptomycin $(100 \mu \mathrm{g} / \mathrm{ml})$ in a humidified atmosphere of $50 \mu \mathrm{g} / \mathrm{ml} \mathrm{CO}_{2}$ at $37^{\circ} \mathrm{C}$.

\section{Development of MCF-7-dox resistant cell line}

The growth of doxorubicin resistance was done through proved method on MCF-7 and the method was followed to create a resistance on MCF-7 cell line against doxorubicin with slight modifications [17]. Associated to the general cell culturing protocol, this current protocol was maintained in DMEM media supplemented with $10 \%$ FBS, penicillin $(100 \mathrm{U} / \mathrm{ml})$ and streptomycin $(100 \mu \mathrm{g} / \mathrm{ml})$ in a humidified atmosphere of $50 \mu \mathrm{g} / \mathrm{ml} \mathrm{CO}_{2}$ at $37^{\circ} \mathrm{C}$ and particularly with Doxorubicin $1 \mathrm{mg} / \mathrm{ml}=1.8 \mathrm{mmol} / \mathrm{l}$ supplementation. The passage was checked and maintained up to $3-4$ mo for the development of resistance.

\section{Cytotoxicity analysis (MTT assay)}

To inspect the cytotoxicity of Au-NPs synthesized and conjugated with doxorubicin synthesized from G. lucidum, cell viability study was carried out with the conventional MTT-reduction assay with small modifications [18]. Briefly, Cells $\left(1 \times 10^{5} /\right.$ well $)$ were plated in 1 $\mathrm{ml}$ of medium/well in 96-well plates (Costar Corning, Rochester, $\mathrm{NY}$ ). The cells were allowed to attach and were grown in a 96-well plate for $48 \mathrm{~h}$, in $200 \mathrm{ml}$ of DMEM with $10 \%$ FBS. After $48 \mathrm{~h}$ incubation, the cell ranges the confluence. Then, cells were incubated with different concentrations of the gold nanoparticles conjugation with doxorubicin viz., 10, 20, 40, 80 and $100 \mathrm{mg} / \mathrm{ml}$ (minimum 3 wells were seeded with each concentration). Equal concentrations of $G$. lucidum extract were used as positive control and the cells were incubated for $48 \mathrm{~h}$. after the addition of MTT (10 $\mathrm{ml}, 5 \mathrm{mg} / \mathrm{ml}$ ), the cells were incubated at $37{ }^{\circ} \mathrm{C}$ for another $4 \mathrm{~h}$. viable cell was determined by the absorbance at $570 \mathrm{~nm}$. Measurements were performed and the concentration required for a $50 \%$ inhibition of viability $\left(\mathrm{IC}_{50}\right)$ was determined graphically. The absorbance at $570 \mathrm{~nm}$ was measured with a UV-Spectrophotometer using wells without sample containing cells as blanks. The effect of the samples on the proliferation of MCF-7-dox was expressed as the $\%$ cell viability, using the following formula:

$$
\% \text { cell viability }=\frac{\mathrm{A} 570 \text { of treated cells }}{\mathrm{A} 570 \text { of control cells }} \times 100 \% .
$$

\section{Comet assay for DNA damage}

Human breast cancer cells in 96-well plates were treated with 0,50 , $100,150,200$, and $250 \mu \mathrm{g} / \mathrm{ml} \mathrm{Au}-\mathrm{NPs}$ synthesized and conjugated with doxorubicin from of $G$. lucidum for $48 \mathrm{~h}$. After the incubation cells were then collected and DNA damage was analysed with the Comet assay [19].

\section{Acridine orange staining assay}

Acridine orange staining assay were studied to find out the morphological sign of apoptosis in Au-NPs synthesized and conjugated with doxorubicin from of $G$. lucidum with treated cells [20]. Cells in 12-well plates were treated with or without 0, 80,120, 180 , and $200 \mu \mathrm{g} / \mathrm{ml}$ gold nanoparticles for $48 \mathrm{~h}$ and stained by using acridine orange (AO) stain.

\section{Mitochondrial membrane potential assay}

Mitochondrial membrane depolarization, a marker of apoptotic cells, revised using a Muse ${ }^{\mathrm{TM}}$ mitopotential assay kit according to the manufacturer's protocol (Merk Millipore, Germany). Previously drypsinization of cells the Au-NPs synthesized and conjugated with doxorubicin were treated with $12 \mu \mathrm{l}$ and $56 \mu \mathrm{l}$. treated cells after study period were trypsinized and washed twice with PBS. The cells were mixed with mitoreagent $(1: 100)$ in dilution buffer provided in the kit and incubated in dark for $30 \mathrm{~min}$. After incubation, the cells were stained with 7-AAD dye $(5 \mu \mathrm{l})$ for $5 \mathrm{~min}$ and analysed in muse. The kit used the principle that high membrane potential drives the accumulation of mitopotential dye within inner membrane of intact mitochondria resulting in high fluorescence. Cells with depolarized mitochondria show a reduction in fluorescence and a down shift. This value is exhibited in the mitopotential axis. A dead cell marker 7-AAD dye is also used as an indicator of cell membrane structural integrity and cell death. It is excluded from live, healthy cells, as well as early apoptotic cells. Dead cells thus show increased fluorescence in the viability axis.

\section{Isolation of mRNA}

The mRNA was isolated from the monolayer of the cell MCF-7 cell line/dox resisted by using the TRIzol kit method (Merk Millipore, Germany). The protocol was employed according to the manufacturer's instructions. 


\section{RNA to cDNA synthesis}

The quality and quantity of isolated mRNA were assessed through UV-Vis spectrophotometer (UV-100Cyberlab USA). Approximately $10 \mathrm{pmol}$ to $1 \mathrm{ng}$ of mRNA was used to synthesis the cDNA. The primer set was Oligod $\mathrm{T}$ (Thymine) which is specific to reverse transcriptase enzyme for synthesis of cDNA and accomplished by the first strand cDNA synthesis kit (NEB).

\section{PCR amplification}

The PCR amplification was executed to the extracted CDNA of MCF-7 cell line. A specific PCR primer set was selecting for ABCB1 gene and it amplified for P-glycoprotein ABCB1. All the PCR reaction was carried out by ABCB1 gene specific primer set under following conditions: $100 \mathrm{ng}$ of genomic DNA, $1 \mathrm{U}$ Taq DNA polymerase, $0.5 \mu \mathrm{M}$ primer set, $400 \mu \mathrm{M}$ dNTP, 10X reaction buffer and $3 \mathrm{mmol} \mathrm{MgCl}_{2}$. Another primer set for TAD specific CDNA was carried out under following conditions: 100ng of genomic DNA, 1U Taq DNA polymerase, $0.2 \mu \mathrm{M}$ primer, $400 \mu \mathrm{M}$ dNTP, $10 \mathrm{X}$ reaction buffer and $1.5 \mathrm{mmol} \mathrm{MgCl}_{2}$ and we obtained final volume was $20 \mu \mathrm{l}$ for both PCR samples.

\section{RESULTS AND DISCUSSION}

In this present report, Au-NPs synthesized and conjugated with doxorubicin were promptly synthesized using $G$. lucidum extract as bio-reluctant. The colour modifications were very first to sign for nanoparticles formation and the clear pinkish violet colour was formed within $30 \mathrm{~min}$ when $1 \mathrm{mmol} \mathrm{HAuCl}_{4}$ was added into the aqueous extract of $G$. lucidum, which indicates the biogenic synthesis of gold nanoparticles (fig. 1). The strength of pinkish violet colour was improved with the incubation time and it was due to the excitation of surface Plasmon vibrations.

In contrast, control (extract alone) very lately, Ravi Geetha et al. (2013) have reported that the aqueous extract of Couroupita guianensis rapidly biosynthesized gold nanoparticles within $5 \mathrm{~min}$ [22].

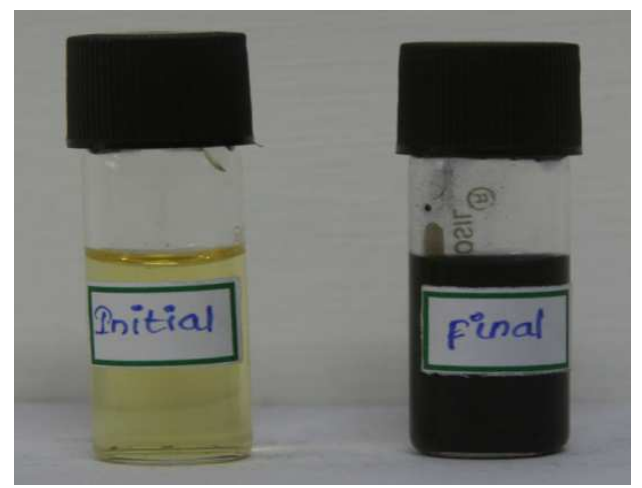

Fig. 1: Mycosynthesis of gold nanoparticles from G. Iucidum

\section{UV-visible spectroscopy}

The gold nanoparticles attained were defined by UV-Vis spectroscopy to screen the reactions of gold nanoparticles formed in the reaction time has the characteristic absorbance showed $\lambda$ max at $537 \mathrm{~nm}$ (fig. 2). In the visible spectra of nanoparticles suspension, UV-visible absorption spectrum of the formed gold nanoparticles absorbs free electrons, which provide surface plasmon resonance (SPR) absorption band since the collective vibration of electrons of gold nanoparticles in resonance with the light wave.

Abroad absorption peak was observed at $537 \mathrm{~nm}$, which is a characteristic band for the $\mathrm{Au}$ [23]. No other peak was observed in the spectrum, so it is reasonable to conclude that the formation of synthesized products is Au only.

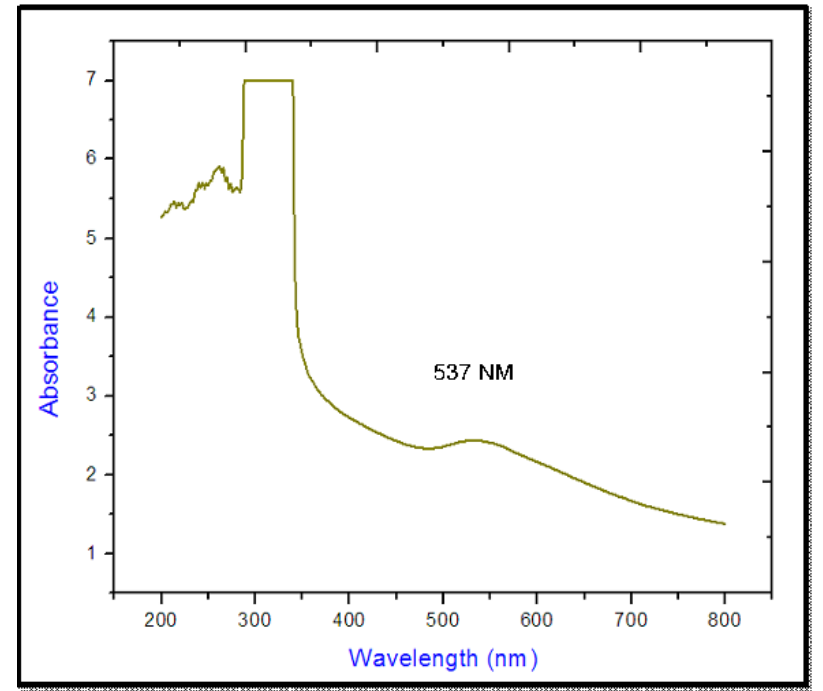

Fig. 2: UV spectrum of G. lucidum mediated gold nanoparticles

\section{FTIR spectral analysis}

Interaction of gold ions and G. lucidum on the formation of AuNps was examined using FTIR spectra. FTIR analysis of G. lucidum exposes strong bands at 3408, 2929, 1645, 1404 and $848 \mathrm{~cm}^{-1}$ (fig. 3). After bio reduction with $\mathrm{HAuCl}_{4}$, a shift in the broad peak at 3408 $\mathrm{cm}^{-1}$ is attributed to the strong interaction of $\mathrm{OH}$ group stretch due to the presence of surface adsorbed alcohols. The previous study discloses that the hydroxyl group $(\mathrm{OH})$ has a strong ability to interact with gold (III) ions [24, 25].

The presence of new peaks at $2929 \mathrm{~cm}^{-1}$ confirms the C-N stretching vibrations of aliphatic amines of proteins (Jilie et al. 2007). Band at $1645 \mathrm{~cm}^{-1}$ was assigned for Alkenyl $\mathrm{C}=\mathrm{C}$ stretch and the band at $1404 \mathrm{~cm}^{-1}$ assigned to $\mathrm{CH}_{2}$ stretching and the band at $848 \mathrm{~cm}^{-1}$ corresponds to C-C stretching vibrations for an aromatic ring.

FTIR spectroscopic study definite the presence of proteins and showed that the protein along with the carbohydrates and polyphenols have the ability to form a layer covering the gold nanoparticles to prevent the agglomeration and stabilizing the gold nanoparticles functionalized G. lucidum. This peak confirms that the obtained product AuNPs, consistent with those reported earlier for biosynthesized gold nanoparticles of G. Sylvestre [26].

\section{EDX analysis}

The elemental composition of the mycosynthesized G. lucidum AgNPs was used by EDXA and revealed in fig. 5. Gold which confirms the elemental composition (75.34 \%) of gold nanoparticles. In EDX analysis, strong Au peaks were observed in G. lucidum and peaks for $\mathrm{Cl}$ were also recorded on observing the Au-exposed G. lucidum. Similar strong signals were obtained around 2.00 and $9.5 \mathrm{KeV}$ for green synthesized gold nanoparticles of Padina boergesenii from our earlier studies [27].

\section{XRD analysis}

The mycosynthesized gold nanostructure by using G. lucidum extract was further proved and confirmed by the characteristic peaks observed in the XRD image at $2 \theta=28.09^{\circ}$, marked with (220). Fig. 4 shows the number of Bragg reflections corresponding to the (220) sets of lattice planes is observed which may be indexed based on the face-centered crystal structure of gold. These sharp Bragg peak influences have carried around bio organic compounds/protein(s) contains in the $G$. lucidum. The XRD pattern thus clearly displays that the AuNPs are crystalline in nature [28]. 


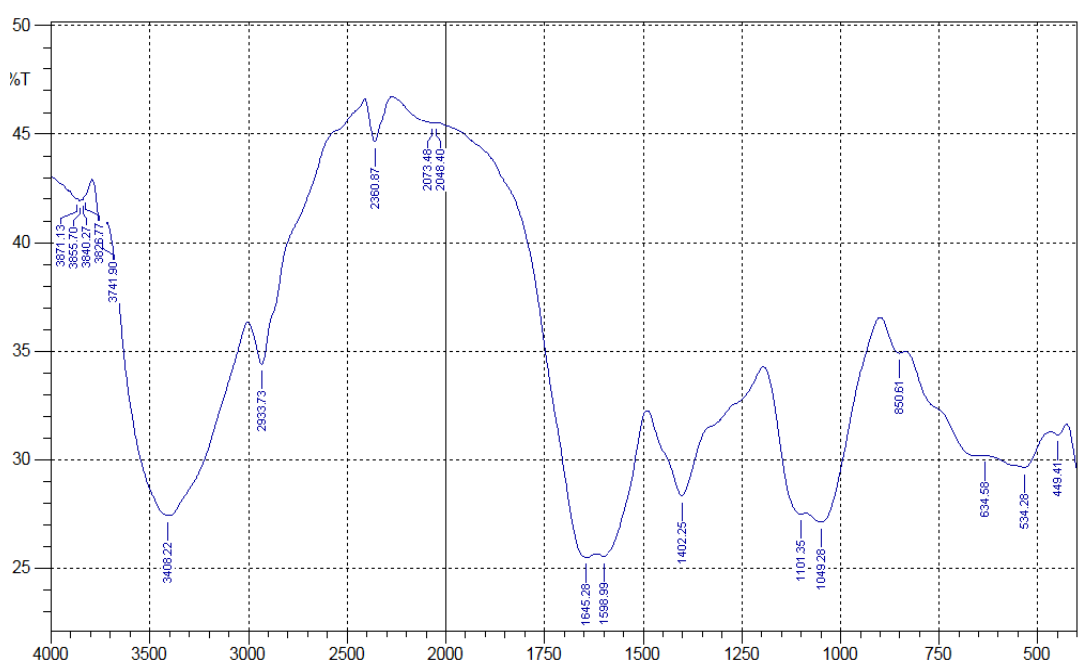

Fig. 3: FTIR spectrum of $G$. lucidum mediated gold nanoparticles

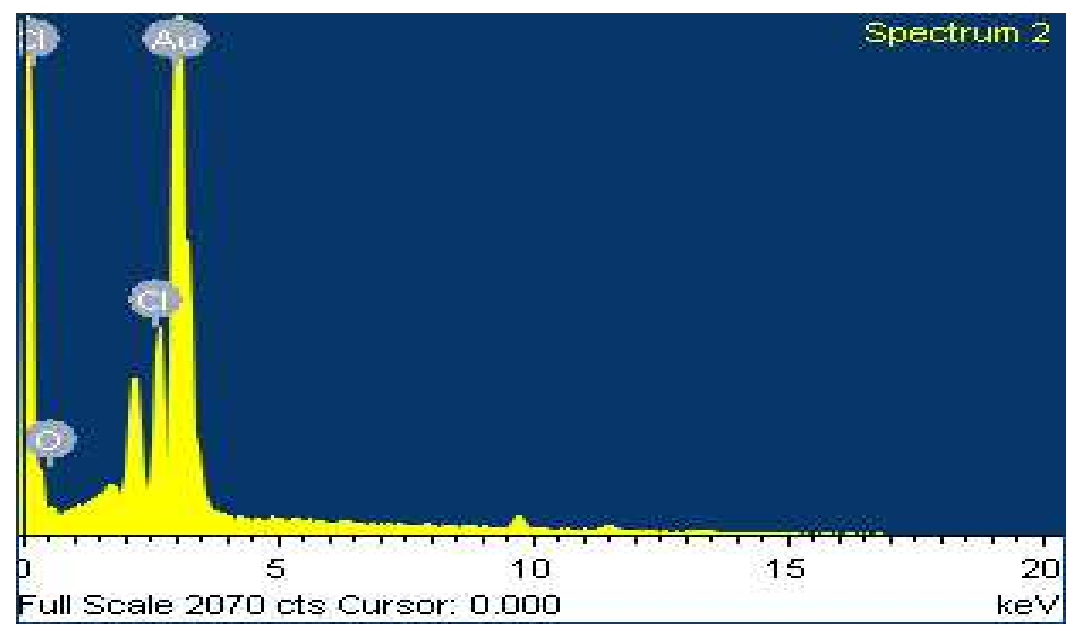

Fig. 4: EDAX spectrum of $G$. lucidum mediated gold nanoparticles

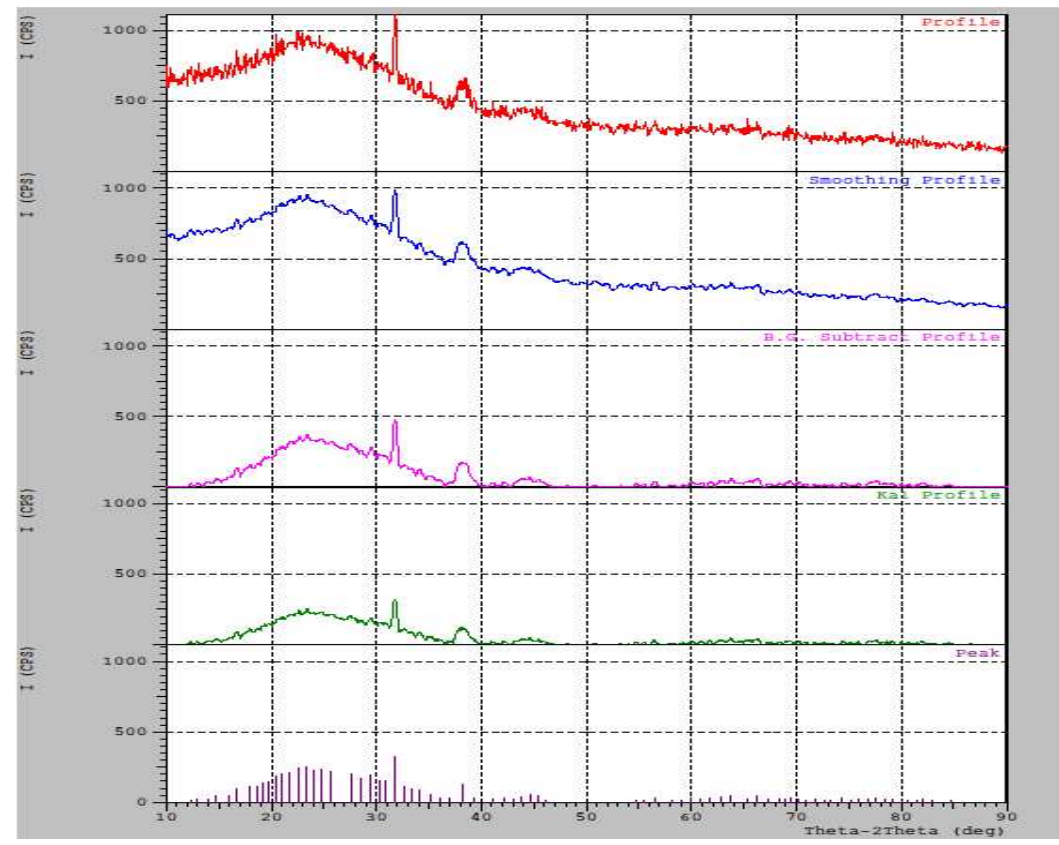

Fig. 5: XRD analysis of G. lucidum mediated gold nanoparticles 


\section{HRTEM analysis}

The HRTEM analysis was studied in the organization Au-NPs from $G$. lucidum that were represented in fig. 6 . The results obtained from HRTEM exhibited formed were predominantly polydispersed and the particles shaped with spherical, hexagonal, and triangular and also displays the crystalline nature of the gold nanoparticles by the selected area electron diffraction (SAED) pattern and the size of the particles ranged from 2-100 $\mathrm{nm}$. The Au-NPs that turn into the support of aqueous extract $G$. lucidum had sizes small adequate to be electron deceptive and imaged as polydispersed small-and largesized nanoparticles with a different diameter.

The current report supports the existences of Au-NPs in G. lucidum, and the results were similar when compared with the earlier reviews of nanoparticles [29].
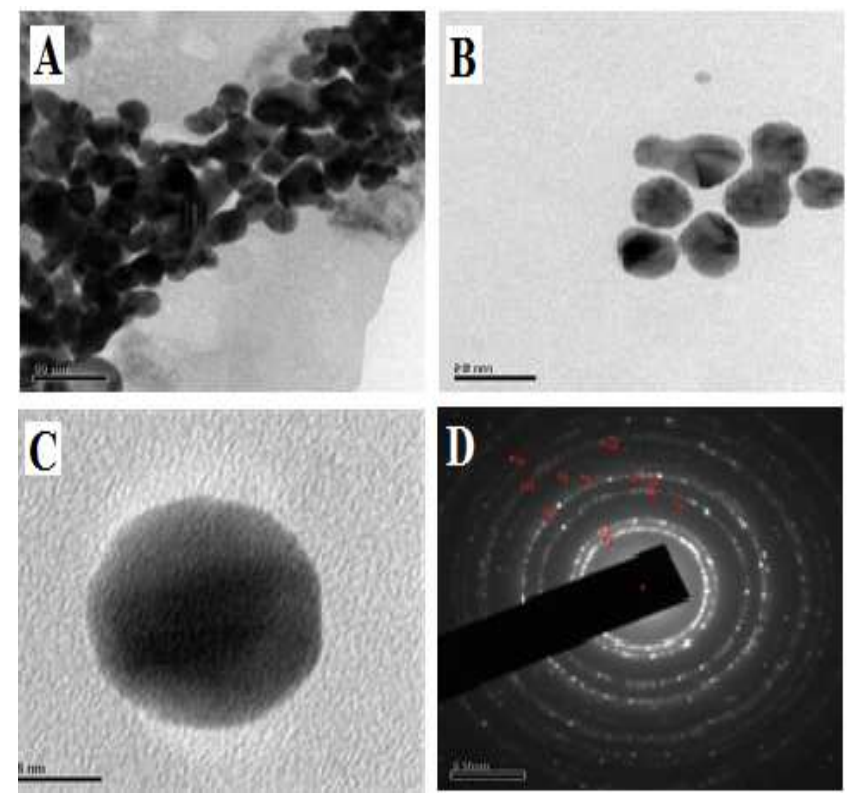

Fig. 6: (A, B and C) HRTEM images of G. lucidum mediated gold nanoparticles (D) SAED pattern analysis of gold nanoparticles

\section{Cytotoxicity assay}

Regardless of the extensive use of Au-NPs synthesized and conjugated with doxorubicin, there are only a few reports to confirm the cytotoxic effects of biologically synthesized gold nanoparticles, predominantly in the setting of apoptosis. The cytotoxicity of the gold nanoparticle conjugation with doxorubicin demonstrated that Au-NPs from G. lucidum had evaluated against resistant MCF-7-doxbreast cancer cell lines at various concentrations $(20-400 \mu \mathrm{M} / \mathrm{ml})$. Fig. 7 shows the cytotoxic activity of bio synthesized gold nanoparticles conjugation with doxorubicin from $G$. lucidum with the $\mathrm{IC}_{50}$ value of $56.16 \mu \mathrm{M} / \mathrm{ml}$.

The highest concentration of AuNPs with $400 \mu \mathrm{M} / \mathrm{ml}$ efficiently inhibited the growth of a MCF-7-dox cell by in excess of $97 \%$. Sankar et al. 2013 [30] reported the anticancer activity of Origanum vulgare mediated silver nanoparticles and cytotoxic effects against human lung cancer A549 cells. In our experiment, the cytotoxicity assay suggested that $\mathrm{IC}_{50}=56.16 \mu \mathrm{M} / \mathrm{ml}$, which is significantly improved than the previous study on MCF-7-dox.

However, the action of AuNPs depends on the nanoparticles size, shape, cancer cells, elapsed time and dosage level. With the proof of above-mentioned report, the $\mathrm{IC}_{50}$ concentration of standard drug doxorubicin alone $100 \mu \mathrm{M} / \mathrm{ml}$ has not been achieved throughout the study on doxorubicin resisted cell line [31]. Due to the doxorubicin resisted cell population has reached 5-10 fold resistance to doxorubicin compared with the normal MCF-7 population proved through MTT assay viability percentage (fig. 7).

But the resisted cell line treated with G. lucidum AuNPs conjugated with doxorubicin has attained the standard $\mathrm{IC}_{50}=56.16 \mu \mathrm{M} / \mathrm{ml}$. The obtained $\mathrm{IC}_{50}$ value is more efficient then the reference and ensured the drug accumulation influx facilitated by G. lucidum Au-NPs synthesized and conjugated with doxorubicin at concentration dependent manner.

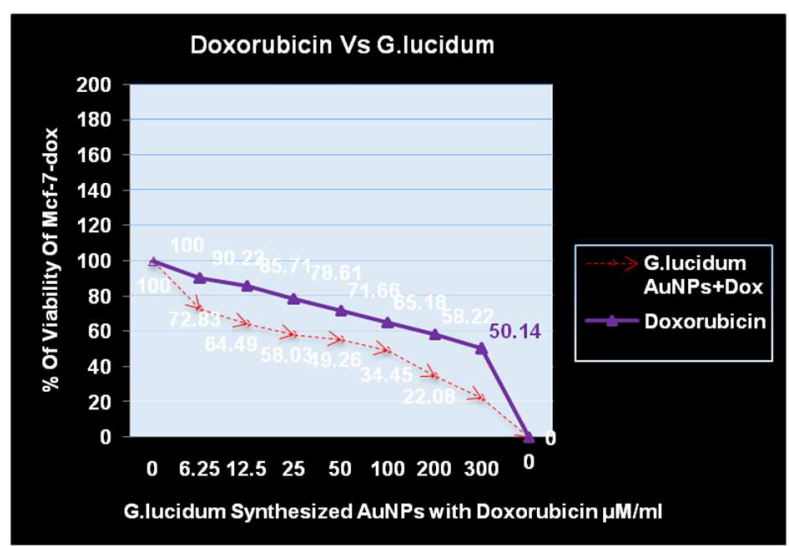

Fig. 7: Cytotoxic activity of $G$. lucidum synthesized gold nanoparticles. G. lucidum synthesized AuNps+doxorubicin IC I0 $_{50}$ value at $50 \mu \mathrm{M} / \mathrm{ml}$ and resistance $5-10$ fold increased against doxorubicin with $\mathrm{IC}_{50}$ value only $400 \mu \mathrm{M} / \mathrm{ml}$

\section{Comet assay}

The various concentrations of Au-NPs synthesized and conjugated with doxorubicin of G. lucidum were performed to determine the DNA damage in MCF-7-Dox, breast cancer cells using this assay. The result observed under fluorescent microscopy reveals uniform spherical shape for control fig. A. Rather in the treated samples illustrates comet tail shaped images (fig. B). The fluorescent microscopy images is apparent that reproducing the nonappearance of any DNA damage control samples and treated sample exhibited DNA single standard break which is clearly observed in MCF-7-doxbreast cancer cell line. Similar type of results was observed in [32]. This confirms gold nanoparticles conjugation with 
doxorubicin has an efficient potency to treat breast cancer cells with a standard drug.

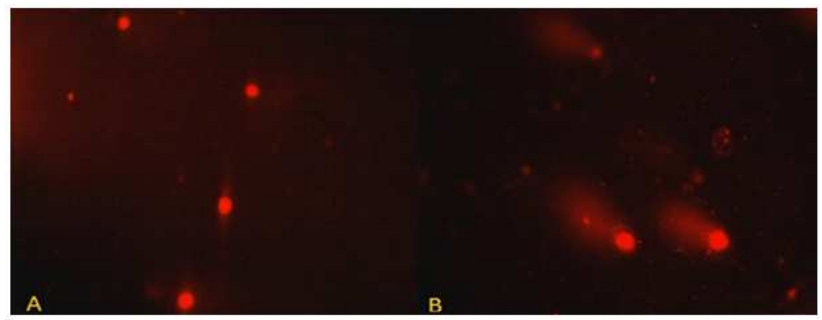

(A) Control

(B) AuNps+Doxorubicin treated

Fig. 8: Assessment of DNA damage by comet assay. No DNA damage was observed in control (A). Single standard break showed as tail

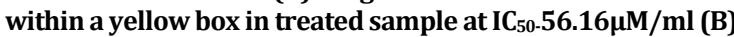

\section{Acridine orange staining assay}

The determination of apoptosis was observed in MCF-7-doxcancer cells, which were treated with different concentrations Au-NPs synthesized and conjugated with doxorubicin of G. lucidum, which was observed with A0 staining, since the control (fig. 9 A) cell appears in light green colour, but in treated cells which appears orange colour (fig. 9 B) the AO staining of treated MCF-7-doxcells showed apoptosis in concentration dependent manner which damages the cancer cells. In this present report, gold nanoparticles treated cells exhibited apoptotic structures for instance condensed nuclei, membrane blebbing and apoptotic bodies at $48 \mathrm{~h}$ and these morphological changes were due to AO staining. It is reasonable to the fact that, Au-NPs synthesized and conjugated with doxorubicin treated MDA-MB-231 cells showed clear fragmented DNA ladders, proposing that cell death is because of apoptosis. Related results were viewed in HL-60 leukaemia cells [33] and also in Silver nanoparticles of Ganoderma neo-japanicum of MDA-MB-231 breast cancer cells [34].

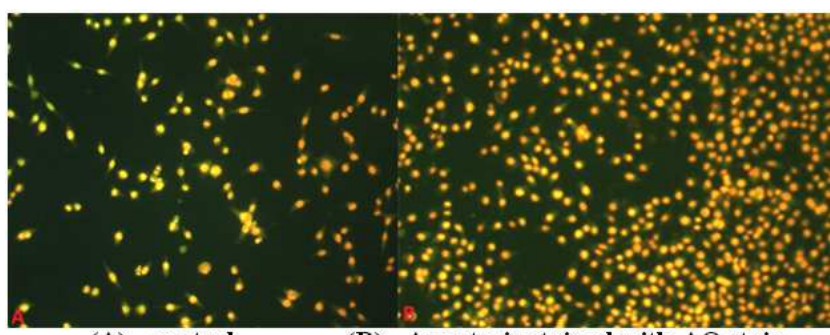

(A) - control

(B) - Apoptosis stained with AO stain

Fig. 9: Determination Apotosis by AO staining. No apoptosis was observed in control (A). Apoptosis showed in treated sample at IC $_{50}-56.16 \mu \mathrm{M} / \mathrm{ml}$ (B)

\section{Mitochondrial membrane potential assay}

The grand support from the report obtained in MTT assay (fig. 9) after the treatment of the G. lucidum synthesized Au-NPs synthesized and conjugated with doxorubicin, which conforms the cytotoxic potential of AuNps together doxorubicin has minimal $\mathrm{IC}_{50}$ value of $56 \mu \mathrm{M} / \mathrm{ml}$ concentration on MCF-7-dox resistance cell line, as like doxorubicin alone on normal MCF-7 cell line. Also with the support of MTT assay, the mitopotential assay was performed to check the minimal $\mathrm{IC}_{50}$ concentration to MCF-7-Dox. The following results confirm the great induction of the apoptotic regulation [35] and drug influx by the G. lucidum synthesized AuNps+Doxorubicin on MCF-7doxresisted strain. The apoptotic pathway was induced through high drug influx and the accumulation of doxorubicin by AuNPs leads open enzymes cascade, makes extreme level of the cell death through the depolarization of the mitochondrial membrane and release of the enzyme such as cytochrome [36], which induces caspase dependent apoptotic function and induction signal was recorded by the mitopential dye 7-AAD of mitopential axis.

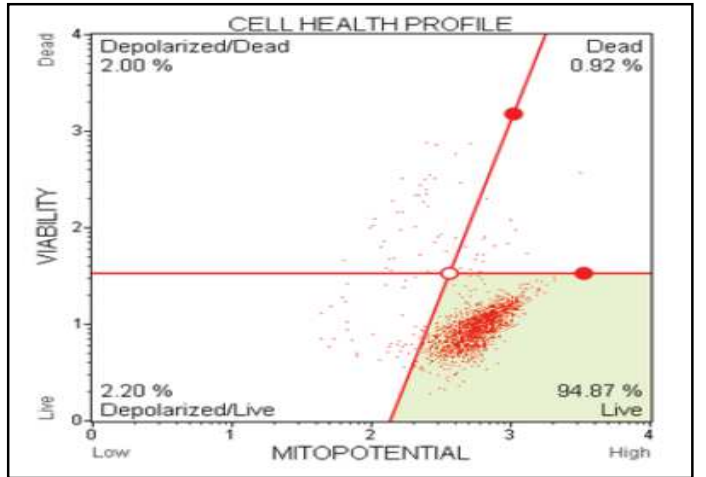

(A). Apoptosis showedin treated sample at $\mathrm{IC}_{50-56.16} \mathrm{MM} / \mathrm{ml}$

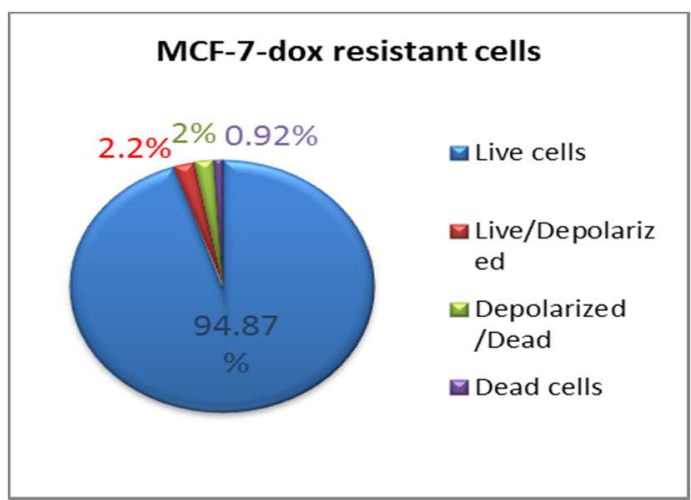

(B) Untreated control MCF-7-dox resisted cells

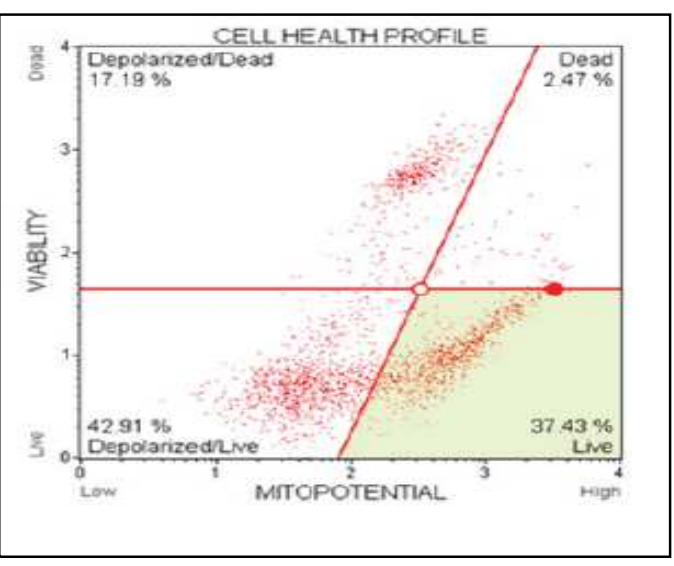

(A) Doxorubicin $\mathrm{IC}_{50}$ at $300 \mu \mathrm{M} / \mathrm{ml}$

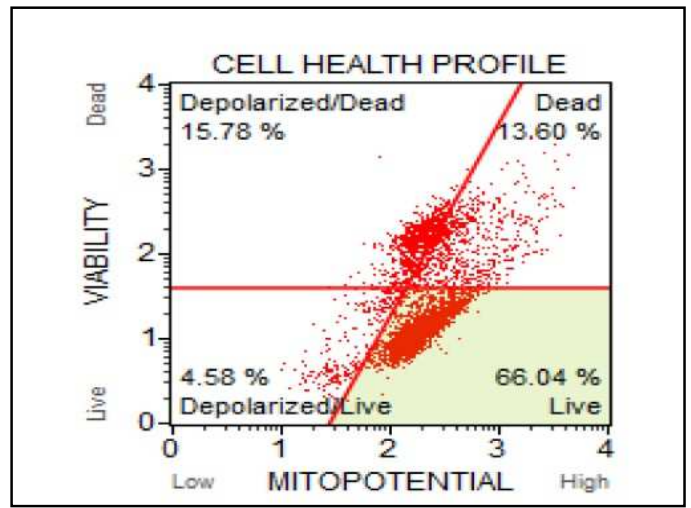

(B) Initial dose AuNPs+dox 


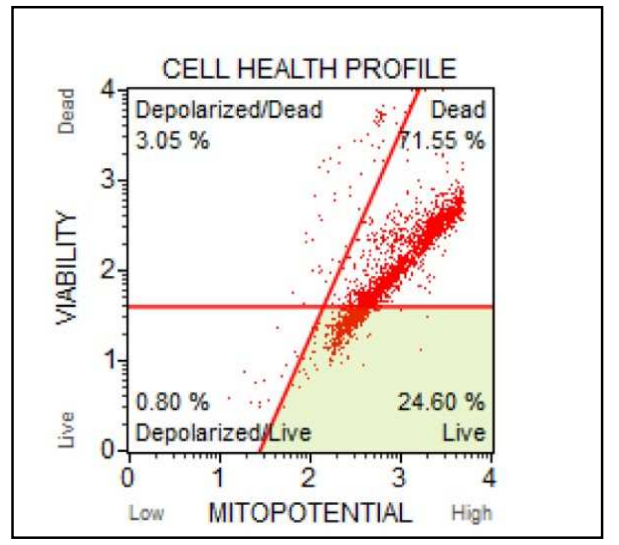

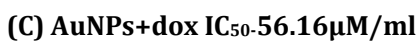

Fig. 10: Determination of mitopotential assay (A) Doxorubicin alone with IC50 attained at $300 \mu \mathrm{M} / \mathrm{ml}$. (B) Initial dose of AuNPs+dox, (C) G. lucidum synthesized AuNPs+dox IC I0- $_{50}$ $56.16 \mu \mathrm{M} / \mathrm{ml}$

\section{mRNA and cDNA analysis}

The mRNA was isolated from MCF-7-dox resisted cell line which was analyzed through gel further which was quantified using a spectrophotometer. The cDNA was synthesized from the mRNA for amplification of the ABCB1 gene corresponding to the specific primer, meanwhile, beta act in the gene was isolated and amplified for comparison fig. 12. A. The amplification is directly proportional to the expression of ABCB1 gene fig. 12. D. with the length of 800$1100 \mathrm{bp}$ approximately. Which shows reduced expression of the $\mathrm{ABCB} 1$ is fully depends on the caspase mediated apoptotic pathway; hence the similar type of resl was obtained in [37].

A
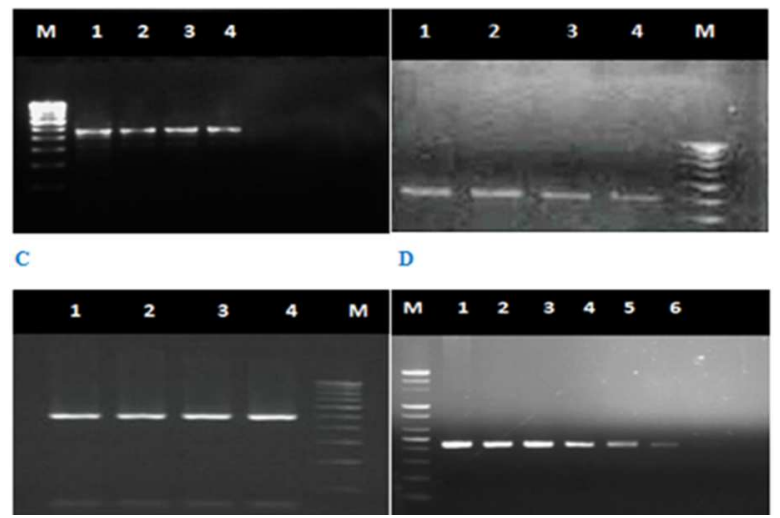

Fig. 11: mRNA isolation, cDNA synthesis and ABCB1 gene expression of MCF-7-dox cell line. A. Beta actin gene expression as a reference. B. mRNA from MCF-7-dox cell line, $C$. cDNA of ABCB1 gene D. reduction of ABCB1 expression by AuNps facilitated doxorubicin treatment lane: 1-6 (by AuNps+Doxorubicin concentration wise)

\section{CONCLUSION}

The current study reported that Au-NPs synthesized and conjugated with doxorubicin can be synthesized by a simple method using $G$. lucidum mushroom extract. All characterization techniques reveal that $G$. Lucidum mediated gold nanoparticles are spherical in shape with an average size 2-100 nm. The efficacy of the Mycosynthesized gold nanoparticles conjugation with doxorubicin showed significant anticancer drug accumulation and activity against MCF-7-dox resisted cell line and serve as an anti-cancer facilitation agent has been determined. mRNA expression of ABCB1 gene and cDNA was synthesized from MCF-7-dox resisted cell line shows reduced expression. The results proposed herein reveal the anticancer activity of Au-NPs synthesized and conjugated with doxorubicin synthesized using $G$. lucidum mushroom extract. It is reasonable to conclude that the pharmacological properties of G. lucidum offer the anticancer activity of newly formed Au-NPs with doxorubicin. Inclusive, though future research in toxicity and in vivo study is required, we recommend that Au-NPs synthesized from G. Lucidum with doxorubicin might be a possible resource of drug delivery for anti-cancer inducing agent preparation that may benefit breast cancer treatment.

\section{ACKNOWLEDGMENT}

The authors are grateful to the authorities of Kongunadu Arts and Science College, Coimbatore, Tamilnadu, India for providing facilities and for their encouragement. The authors would like to acknowledge Department of Nano Science and Technology, Karunya University for the XRD and EDX analysis. We extend our thanks to Dr. Anuradha Ashok, Nanotech Research Facility, PSG Institute of Advanced Studies, Tamil Nadu, and India for the HRTEM analysis.

\section{CONFLICT OF INTERESTS}

Declared none

\section{REFERENCES}

1. Graham LE, Cook ME, Busse JS. The origin of plants: body plan changes contributing to a major evolutionary radiation. Proc Nat Acad Sci USA 2000;97:4535-40.

2. Falster DS, Westoby M. Plant height and evolutionary games. Trends Ecol Evolution 2003;18:337-43.

3. Kasthuri JS, Veerapandian S, Rajendiran N. Biological synthesis of silver and gold nanoparticles using apiin as reducing agent. Colloids Surf B 2009;68:55-60.

4. Baker S, Satish S, Endophytes. Towards a vision in the synthesis of nanoparticle for future therapeutic agents. Int J Bio-Inorg Hybd Nanomater 2012;1:1-11.

5. Mohanpuria P, Rana KN, Yadav SK. Biosynthesis of nanoparticles: technological concepts and future applications. J Nanopart Res 2008;10:507-17.

6. Casida JE, Quistad GB. Insecticide targets: learning to keep up with resistance and changing concepts of safety. Agric Chem Biotechnol 2005;43:185-91.

7. Sastry M, Ahmad A, Khan MI, Kumar R. Microbial nanoparticle production. In: Niemeyer CM, Mirkin CA. editors. Nanobiotechnology. Wiley-VCH. Weinheim. Germany; 2005. p. 126-35.

8. American Cancer Society. Cancer Facts and Figures. Atlanta: American Cancer Society; 2015.

9. Brown K. Breast cancer chemoprevention: risk-benefit effects of the anti-oestrogen tamoxifen. Expert Opin Drug Saf 2015;1:253-67.

10. Liu AR, Chen SC, Jin W. Host specificity of Endophytic Pestalotiopsis populations in mangrove plant species of South China. J Microbiol Res 2012;6:6262-9.

11. Seigneuric R, Markey L, Nuyten DS. From nanotechnology to nanomedicine: applications to cancer research. Curr Mol Med 2010;10:640-52.

12. Wasser SP, Coates P, Blackman M. Reishi or Lingzhi (Ganoderma lucidum). encyclopedia of dietary supplements. New York: Marcel Dekker; 2005.

13. Ha TB, Gerhauser C, Zhang WD. New lanostanoids from Ganoderma lucidum that induce NADPH: quinone oxidoreductase in cultured hepalcic7 murine hepatoma cells. Planta Med 2000;66:681-4.

14. Chang ST, Mshigeni KE. Mushroom and Human health: their growing significance as petent dietary supplements. University of Namibia, Windhoek, Namibia; 2001. p. 79.

15. Kim HW, Kim BK. Recent advances on the biologically active triterpenoids of Ganoderma lucidum. In: ZB Lin. editor. Ganoderma: Genetics, Chemistry, Pharmacology and Therapeutics. Beijing Medical University Press: Beijing; 2002. p. 10-9.

16. Fang QH, Zhong JJ. Submerged fermentation of higher fungus Ganoderma lucidum for the production of valuable bioactive metabolites-ganoderic acid and polysaccharides. Biochem Eng 2002;10:61-5. 
17. Ranjith Santhosh Kumar DS, Lakshman Kumar B, Senthil Kumar P. Biomimetic of silver nanoparticles from ganoderma lucidum (curtis) p. karst and its anti-cancer potential on breast cancer cells. Int J Adv Multidiscip Res 2015;2:903-9.

18. Mossman T. Rapid colorimetric assay for cellular growth and survival: application to proliferation and cytotoxicity assays. J Immunol Meth 1983;65:55-63.

19. Chen JC, Lu KW, Lee JH. Gypenosides induced apoptosis in human colon cancer cells through the mitochondria-dependent pathways and activation of caspase-3. Anticancer Res 2009;26:4313-26.

20. Winnicka F, Bielawski K, Bielawska A. Apoptosis-mediated cytotoxicity of ouabain, digoxin and proscillaridin an in the estrogen independent MDA-MB-231 breast cancer cells. Arch Pharm Res 2007;30:1216-24.

21. Rajesh Ramachandran, Mini Saraswathy. Up-regulation of nuclear-related factor 2 (NRF2) and antioxidant responsive elements by metformin protects hepatocytes against the acetaminophen toxicity. Toxicol Res 2004:3:350.

22. Ravi Geetha, Thirunavukkarasu A, Selvaraj T. Green synthesis of gold nanoparticles and their anticancer activity. Cancer Nanotechnol 2013;4:91-8.

23. Krishnakantha TP, Lokesh BR. Scavenging of superoxide anions by spice species. Indian J Biochem Biophys 1993;30:133-4.

24. Lin Z, Wu J, Xue R. Spectroscopic characterization of Au3+biosorption by waste biomass of saccharomyces cerevisiae. Spectrochim Acta A 2005;61:761-5.

25. Ganesh Kumar V, Gokavarapu SD, Rajeswari. Facile green synthesis of gold nanoparticles using leaf extract of antidiabetic potent Cassia auriculata. A Colloids Surf B: Biointerf; 2011. p. 87-159.

26. Jilie K, Shaoning YU. Fourier transform infrared spectroscopic analysis of protein analysis of protein secondary structures. Acta Biochim Biophys Sin 2007;39:549-59.

27. Gole A, Dash C, Ramakrishnan V. Pepsingold colloid conjugates: preparation, characterization and enzymatic activity. Langmuir 2001;17:1674-9.

28. Senthilkumar P, Bhuvaneshwari, Janani. The potent aglucosidase inhibitory activity of green synthesized gold nanoparticles from the brown seaweed Padina boergesenii. Int J Adv Multidiscip Res 2015;2:917-23.
29. Shankar SS, Rai A, Ahmad A. Rapid synthesis of Au, Ag, and bimetallic $\mathrm{Au}$ core-Ag shell nanoparticles using neem (Azadirachta indica) leaf broth. J Colloid Interface Sci 2004;275:496-502.

30. Senthilkumar P, Bhuvaneshwari, Janani. Potent a-glucosidase inhibitory activity of green synthesized gold nanoparticles from the brown seaweed Padina boergesenii. Int J Adv Multidiscip Res 2015;2:917-23.

31. Sankar R, Karthik A, Prabu A. Origanum vulgare mediated biosynthesis of silver nanoparticles for its antibacterial and anticancer activity. Colloid Surface B 2013;108:80-4.

32. Chen JC, Lu KW, Lee JH. Gypenosides induced apoptosis in human colon cancer cells through the mitochondria-dependent pathways and activation of caspase-3. Anticancer Res 2009;26:4313-26.

33. Thirunavukarasu A, Durai P, Ravi G. Apoptosis in liver cancer (HepG2) cells induced by functionalized gold Nano particles. Colloids Surfaces B: Colon Bio Interfaces 2014;123:549-56.

34. Ravi Geetha, Thirunavukkarasu A, Selvaraj T. Green synthesis of gold nanoparticles and their anticancer activity. Cancer Nanotechnol 2013;4:91-8.

35. Finkel E. The mitochondrion: is it central to apoptosis? Science 2001;292:624-6.

36. Hearps AC, Burrows J, Connor CE, Woods GM, Lowenthal RM, Ragg SJ. Mitochondrial cytochrome $\mathrm{C}$ release precedes transmembrane depolarization and caspase-3 activation during ceramide-induced apoptosis of Jurkat $\mathrm{T}$ cells. Apoptosis 2002; 7:387-94.

37. Mansoori M, Golalipour M, Alizadeh S, Jahangirerad A, Khandozi S, Fakharai H, Shahbazi M. Genetic variation in the ABCB1 gene may lead to mRNA level change: application to gastric cancer cases. Asian Pac J Cancer Prev 2015;16:8467-71.

\section{How to cite this article}

- DS Ranjith Santhosh Kumar, P Senthilkumar, L Surendran, B Sudhagar. Ganoderma lucidum-oriental mushroom mediated synthesis of gold nanoparticles conjugated with doxorubicin and evaluation of its anticancer potential on human breast cancer MCF-7/DOX cells. Int J Pharm Pharm Sci 2017;9(9):267-274. 